\title{
Modern Reconstruction of Mesoamerican Musical Culture Elements in Educational Process
}

\author{
Vladimir Lisovoi \\ Russian State Specialized Arts Academy \\ Moscow, Russia \\ e-mail: foxenger@mail.ru
}

\begin{abstract}
The tendency to use interdisciplinary methods in the reconstruction of elements of ancient musical cultures characterizes the musicological and musical approaches in Northern and Latin America and the Europe countries in the XX-th century. Scientific reconstruction's method is based on special musical terminology sources studying in their historic and cultural contexts. The first type of Mesoamerican musical terminology has included the general concepts designating an essence of musical-cultural phenomenon as a whole in sphere of ontologic representations (the concepts "sound" and "sounding"). The second type has been connected with an explanation of various concepts of musical culture, including musical practice. The creative reconstruction's method represents individual author's character but it can be objective. Different mythological symbols, archaeological objects and architectural monuments become a source of inspiration for Mexican and Guatemalan musicians and composers. It's necessary and possible to apply these methods in educational process and the author of the article does it.
\end{abstract}

Keywords-Mesoamerican vocal and instrumental music; cuicatl; "Rabinal Achi"; Latin American music; C. Chavez; S. Revueltas

\section{INTRODUCTION}

The theme of the article is devoted to one of the important problems of modern archeomusicology. It concerns the scientific and creative reconstruction of Mesoamerican musical culture elements in modern educational process and musical creativity. There is the experience of the reconstruction in the teaching in Moscow State Specialised Academy of Arts where we with students study ethnic musical traditions and music cultures around the world during last twenty two years. Mesoamerican music as a part of ancient musical culture takes one of the most important places in the studies so possibility of its reconstruction in own creative experience is based on research of different scientific sources. We use the scientific and creative reconstruction's elements in theorethical and practical courses with analyze of musical terminology, iconography and mythological symbols and compose music works in styles of modern Mexican and Guatemalan composers.

There is a serious tradition of scientific study of Mesoamerican culture in Russia. The epic text "Popol Vuh" and historical book "Annales de los Senjores de
Totonicopan" as well as the works by D. de Landa, B. Diaz del Castillo and B. de las Casas were translated into Russian in the twentieth century. Modern Russian scientist G.G. Yershova continues the traditions of her teacher, the outstanding soviet researcher and translator Y.V. Knorozov and his collegae, the famous historian R.V. Kinzhalov. There are many works on the South, Central and North American culture and mythology, Latin American and Spanish music by Y.E. Berezkin ("Kunstkamera", St.Petersburg), M.A.Saponov and I. A Kryazheva (Department for Foreign Music History, Moscow State Tchaikovsky conservatory; A.V. Dotsenko (Moscow Institute for Latin American Studies).

For preparing of our courses we use their works and the books on Mesoamerican musical culture's and modern Indians musical traditions' themes by R. Stevenson [1], S. Marti [2], P. Collaer [3], G. Chase [4], V.T. Mehdoza [5], R.E. Lizardi [6], B.A. Vasgues [7], N. Hammond [8], S. Rendon [9], R.M. Campos [10], J.H. Cornyn [11], J.C. Romero [12], H. Yurchenko [13], M.L. Simmons [14] and other authors.

The kinds of Mesoamerican music, musicians and music repertoire are described by the researchers very well, and this information can give the impulse for the understanding of specificity of both modern Indians traditional music and composers' works too. One of the main features of the ancient musical culture is its sincretic connections with dance, poetry, religious rituals and social life at all so Mesoamerican music culture's studies are based on the sincretic concept. Our experience of scientific reconstruction includes the research of music elements in Mayan and Nahuatl mythological systems. The sound concept is treated with the special musical terminology and wide cultural context of musical life.

\section{ABOUT THE SCIENTIFIC RECONSTRUCTION OF MesoAmericAn Musical CUlture ElEMENTS}

Scientific reconstruction of material and spiritual cultures elements of ancient civilisations is characteristic for archaeological, historical, ethnological, anthropological, culturological, philological and other directions in their studies. As a result of their interactions the interdisciplinary approach can create the objective scientific representations or adequate "cultural picture" of historical events. The 
tendency to use the interdisciplinary methods in the reconstruction of elements of ancient musical cultures is characterised for the musicological approaches in Northern and Latin American and the European countries in the twentieth century. One of such methods is based on special musical terminology sources studying in their historical and cultural contexts.

The basic sources for Mesoamerican musical culture and musical terminology studies are texts in a Latin publishing in Mexico and Spain and including the epos "Popol Vuh", "Manuscript Chi", the religious book "Chilam Balam", "El Libro de los cantares de Dzitbaltche", the poetic text of a dance-drama "Rabinal Achi", epic songs, divine hymns, epigraphical inscriptions, hieroglyphic texts in the Parisian, Dresden and Madrid codes, the works, memoirs and notes by Spanish missionaries (B. de Sahagun), soldiers, etc. Mayan and Nahuatl musical notations, the descriptions of musical instruments and the collection "Cantares Mexicanos" with Nahuatl texts in Latin are interesting for students in their work especially.

We with students study two basic terminological types which were extended in Mesoamerican musical culture. The first type included the general concepts of musical-cultural phenomenon as a whole in sphere of ontologic representations. There were described the concepts "sound" and "sounding" as certain types of musical-cultural mentality and principal views to music.The term "cacuitztiliztli" ("sound") was connected with concept of space because they believed it was possible to "hear" ("cacui") space sound vibrations ("cacuitia" - "the soundings coming from the outside") and then "to explain" or "to interpret" ("cacuiztilia") their value. For distinction of a sound and sounding characteristics the ontologic concept "in xocitl in cuicatl" ("a flower and a song") was used. The term included both a designation of a certain musical-poetic genre ("songs-flowers") and a symbol of philosophical explanation of the world laws.

Mesoamerican philosophers "tlamatinime" believed in a dream and an illusion of the life. They knew only creative process was a unique way to true knowledge, it was the way of musical-poetic inspiration and metaphors, the way of "flowers and songs". However, this term had both deep ethical and aesthetic senses so it was connected with a concept "iztli in yolteotl" ("a face and heart") which defined a source of movement and life. The concept could be understood with "moral kindness" of the concept "in xocitl in cuicatl" which placed the God in true human heart and blossomed in art, in creation of fine things. The second type of musical terminology was connected with an explanation of various concepts of musical culture including musical practice. It's possible to allocate three groups of the terms:

- musical repertoire,

- musical instruments,

- musicians, their place and functions in society.

When students study Mesoamerican musical culture it is important to understand in it there wasn't used the general concept which was similar to modern western term "music". In a syncretic complex of art expressive means the music was connected with a poetic word, a dance and a ceremony.

\section{ABOUT MESOAMERICAN VOCAL AND INSTRUMENTAL MUSIC}

The poetry was sung and danced and for the designation of the phenomena the concept "cuicatl" was accepted. Different kinds of "cuicatl" were sung by poets and singers "cuicani" and made important part of religious rights in honour of gods (the general term "teocuicatl", song for the god Tochtli "Tochcuicatl"), military events (sacrifice songs "cuapizcuicatl", "cuatezoncuicatl", songs with military drum teponaztli "teponazcuicatl", glorifications "teuccuicatl"), court ceremonies (spring songs "xopancuicatl" and philosophic songs of flowers "xochicuicatl" including sad songs "icnocuicatl"), secular rituals of life cycle (wedding song "cococuicatl", singing of young girls "azozococuicatl", love songs "siuacuicatl" and "ahuilcuicatl" or "ixcuecuecuicatl", funeral songs "miccuicatl"). The special term "melahuacuicatl" meant "true, perfect, correct singing" or "divine beauty".

There were also many ethnic styles of "cuicatl" which used as various capital Tenochtitlan's styles during festivals ("huexotzincuicatl", "otoncuicatl”, "oztomecayotl”, "nonoalkayotl", "cozcatecayotl", "cuextecayotl" as "singing for pleasure", "anahuacayotl" as "singing with feelings of a celebration").

The special musical terms in ancient Mayan language were represented by the names of musical instruments. It's interesting the interpretation of main percussion instruments (idiophone, slit drum "teponaztli" and membranophone, vertical drum "huehuetl") was connected with their ritual functions as receptacles of deities on a pyramid before temples. The value of wind musical instrument was conveyed in term "atecocolli" ("a sea shell" or "giving a pleasure"). Ensemble music was considered as means of collective expression, ensembles could consist of singers, instrumentalists and dancers. In the collection "Cantares Mexicanos the verbal text designating quantitative structure and the syllabic notation with onomatopoeic words "toco", "tico", "coto", "titi" etc. was used.

The comparative way of the study of Mesoamerican musical culture is widely applied by students. It is known in Central American Indian societies the development of poetry, ritual dance and music was promoted by priests and great artists which with nobility protection were often appointed to the highest posts in scientific and cultural spheres. "Tlacuilo" ("creator" and "artist") was the central concept of the musician as a person who was born with patronage of gods of arts, had "divine inspiration" and could talk with a human heart and reach the condition the god entered into it. Artists used the help of gods, the patron of music and musicians was god Macuilxochitl ("five flowers").

Aztecs poets, musicians, sculptors and painters received a rank "toltec" as successors of great ancient Toltec cultural tradition. They had also the skillful "tlacuilo" as the highest 
degree "yolteotl" ("the divine heart"). It was necessary for temple, court and military musicians and priests "tlamascue" in temple "cu" to study astrology, chronology and other sciences, arts, texts of divine songs and singing in school of arts "calmecac". One of the main teachers of all temple singers was priest "ometochzin", a priest "tlapizcatzin" made the necessary corrections to texts of the celebratory songs in honour of gods. Temple singers "tlapixcatzin" ("a person who keeps the tradition") kept correct ritual and ceremonial singing, developed the art of divine songs. Scientific studies of singing songs "cuicatl" were carried out "cuicamatini" ("scientist, expert") and named "cuicatlamatiliztli" ("knowledge of the singing"). As music was a part of the ritual the priest's opinion about songs was very important for the musicians and composers.

Music played the important role in social life of Mesoamericans so singers and instrumentalists had high social prestige. Musicians and the authors of songs "cuicatl", composers "cuicani" were invited in "cuicacalli" ("houses for singing") where they performed laudatory songs "yaocuicatl" in honor of the leaders and theirs military victories. "Tlamatinime cuicacalli" as "a hall of the science and music" with a drum "huehuetl" in the centre was in palace of the governor of Teskoko city Nosahualcoyotl where military leaders, poets and musicians sang songs. In the hall "mixcoacalli" dancers in the painted masks, singers and musicians with flutes, drums "huehuetl" (musician "huehueto") and "teponaztli" (musician "teponazo"), rattles "ayacachtli", "totzilakatl” and "omichicauaztli".

\section{AbOUt The CREATIVE ReCOnStRUCTION OF MESOAMERICAN MUSIC ELEMENTS}

In addition to scientific reconstructioning in educational process the creative reconstruction is one of the modern way for the study of ancient cultures and music. It represents individual author's (composer's) character but at the same time it can be objective. The plots and symbols of myths, legends, fairy tales, rituals, ceremonies, archaeological objects and architectural monuments become a source of inspiration for musicians and composers to create images of ancient cultures. Operas "The Snow Maiden", "Sadko" and "Kitezh" by N.A. Rimsky-Korsakov, ballet "The Rite of Spring" ("Sacred Spring") by I.F. Stravinsky, compositions by many Latin American composers wouldn't be written without application of creative reconstruction of prehistoric and ancient Slavs' customs or Indians rites and ceremonies.

The first samples of creative reconstruction of the Mesoamerican music in Central American culture were connected with interest to American Indian folklore of ethnographers, writers and artists at the end of nineteenth century. "Guatimotzin" (1871) by A. Ortega del Villar with a libretto by J. Cuellar was the first opera on Mesoamerican history plot.

In twentieth century Mesoamerican culture and music were images for musical work by Mexican and Guatemalan composers. Indian theme was main in ballets "El fuego Nuevo", "Los cuatro soles", "La hija de Cólquide" and "Pyramide"; choral composition "Imágen mexicana" and "Canto a la tierra"; ensemble piece "Xochipili"; "Sinfonía india" by C. Chavez and symphonic plays "Sensemaya" and "Nuit de Maya" by S. Revueltas, etc. $[15 ; 16 ; 17 ; 18 ; 19 ; 20$; 21; 22]. C. Chavez, D. Ajala Perez, K. Huisar, S. Revueltas, B. Galindo-Dimas, F. Dominges, L. Sandi, R. Herrero, E. Hernandes Moncada, V. Mendoza and H.P. Monkajo developed the new direction which was named indihenism. They believed it was necessary to return to ideas of Mesoamerican music for the modernization of the musical language in composers' works. C. Chavez together with F. Domingues and L. Sandi collected Indian musical folklore at expeditions, J. Castilo wrote ethnomusicological work about Maya-Quiche musical traditions in Guatemala.

C. Chavez and J. Castillo impressed mythological and historical images and were the first composers who used Mesoamerican ancient and Indian modern traditional musical instruments in the symphonic orchestra C. Chavez included the scraper and the suspended spongy stick in the score of "Imágen mexicana" as well as a drum and a rattle guire in the score of "Sinfonía india". J. Castillo used melodic phrases of Indian church chanting in his compositions. In "Sensemaya" by S. Revueltas picture of creation of the world from the first vibration and four elements (water, air, fire and the earth) as well as images of mythological animals (a jaguar, a snake) and birds is represented, a scraper and a small American Indian drum are used with western instruments widely.

Mexican and Guatemalan composers also imitated the sounds of Indian musical instruments with the western orchestra's mean. For example, in "Sinfonía india" by C. Chavez the sounds of traditional American Indians wooden flutes, drums "teponaztli" and "huehuetl" can be heard in timbres of a flute piccolo, a xylophone, timpani, a big drum, a tenor drum and a metal rattle. S. Revueltas in "Sensemaya" used for that a xylophone (timbre of "teponaztli"), a bass drum and tam-tam (timbre of "huehuetl"). In "Nuit de Yucatan" final variations of "Nuit de Maya" by S. Revueltas a picture of American Indian traditional ceremony appears before the listeners with a help of a xylophone and hand bells (timbre of "teponaztli") and drums (timbre of "huehuetl").

The composers developed a musical material with the expressive ways of American Indian traditional ensembles' music-making as ostinato formulas (percussion instruments of orchestra). The traditions are continued in musical works by modern Mexican composers, for instance, in the symphonic composition "Cuicatl" by J. Parejon. In Guatemalan academic music of first half XX of century the creative reconstruction is presented in such works by $R$. Castillo as ballet "Paal Caba" with its symbolic atmosphere of a sacrifice ceremony, symphonic compositions "Xibalba" on Maya-Quiche epos "Popol-Vuh" theme and a piano cycle "Guatemala" representing American Indian ritual dances. In modern Guatemalan music the creative reconstruction is used in the choral work "Juego de pilote" by D. Lehnhoff.

For the understanding of the specifics of composer's creative process it's important to use in the training the comparative way of studies of structures and patterns in 
ancient and modern music. In practical teaching it's possible to demonstrate to students the modern musical works in which Mesoamerican music's and culture's elements can be found. The first music example for students can be "Son de Quiche-Achi" from the "Rabinal Achi" dance drama recording by $\mathrm{H}$. Yurchenko in Guatemala. The instrumental ensemble consists of three musicians. Where students listen to this music they try to consider the specific of its sounds, timbres, rhythmic structures and instrumental functions with their links with the plot of drama and historical and cultural context. In the modern Indian instrumental ensembles in Central America the elements of ancient ceremonial practice remain.

Functions of the musical instruments are divided into several kinds which have certain value in ensemble as well as participants groups play their roles in a ceremony. Two functional models are characterized for instrumental ensembles. The double model includes the instrument-leader and the instrument-partner; the triple model includes the functions of instrument-leader, instrument-partner and the supporting musical instrument(s). We can hear the triple model acting in the "Son de Quiche-Achi" with the first trumpet as a leader, the drum tun as a partner and the second trumpet as a support.

The same connections between the ensemble instruments can be found in the fragment from the symphonic work by S. Revueltas "Nuit de Maya". The triple model acts at the last movement of the composition "Nuit de Yucatan" where the violins are leaders, the percussions are partners and the aerophones have supporting functions. The composition "En el Atrio de la Vieha Iglesia" from piano cycle "Guatemala" by R. Castillo arranged for the symphony orchestra by modern Guatemalan composer R. Asturias include another kind of the triple model. It is expressed by means of one instrument which imitates a flute or chirimia as a leader, drums as supporting instruments and winds as partners.

\section{CONCLUSION}

As a result of studying of ancient Mesoamerican Indians and modern Mexican and Guatemalan composers' music the students' musical works appear.

\section{REFERENCES}

[1] Stevenson R. Music in Aztec and Inca Territory. Berkeley, Los Angeles and London, 1968.

[2] Marti S. Canto, danza y musica precortesianos. Mexico, 1961.

[3] Collaer P. Amerika. Musikgeschichte in Bildern. B.1 L.2. Leipzig: DVFM.

[4] Chase G. Americas Music. Chapter XX: Indian Tribal music. - New York, Toronto, London, 1955.

[5] Mendoza V.T. Panorama de la musica traditional de Mexico. Mexico, 1956.

[6] Lizardi R.E. La Musica Precortesiane. - Guadernos americanos. Mexico, 1956, Vol. XV, N 1.

[7] Vasguez B.A. El Libro de los cantares de Dzitbaltche. Mexico, 1965.

[8] Hammond N. Classic Maya Music. Cambridge, Mass., 1972.

[9] Barrera Vasgues.A., Rendon S. El libro de los libros de Chilam Balam. Mexico, 1948
[10] Campos R.M. El folklore y la musica mexicana. Mexico City, 1928.

[11] Cornyn J.H. The song of Quetzalcoatl. Ohio, 1930.

[12] Romero J.C. Musica Precortesiana. Mexico City, 1947.

[13] Yurchenko H. Indian Music of Mexico and Guatemala. // Bul. of the American Musicological Society, 1948, Vol. XI-XIII. P. 58

[14] Simmons M.L. Pre-Conquest Narrative Songs in Spanish America // Journal of American Folklore, Bloomington, 1960, Vol. LXXIII.

[15] Weinstock H. Carlos Chávez. Musical Quarterly, xxii, 1936. P. 435445.

[16] Mayer-Serra O. Silvestre Revueltas and Musical Nationalism in Mexico // Musical Quarterly 27, 1941. P. 123-145.

[17] Cowell H. Chávez. The New Book of Modern Composers, 1961. P. 443-446.

[18] Carmona G. La música de Carlos Chávez. - Carlos Chávez: homenaje nacional. Mexico City, 1978. P. 115-128.

[19] Parker R.L. Chávez and the Ballet // Dance Chronicle, viii, 1985. P. 179-210

[20] Parker R.L. Carlos Chávez: A Guide to Research. Routledge, 1998.

[21] Zohn-Muldoon R. The Song of the Snake: Silvestre Revueltas' Sensemayá // Latin American Music Review / Revista de Música Latinoamericana 19, no. 2 (Autumn), 1998. P. 133-159.

[22] Bonilla R.G. Carlos Chávez y Silvestre Revueltas, la leyenda de una pugna // Correo del Maestro. Núm. 43, diciembre 1999. 